\title{
PROFIT EQUALISATION RESERVE AND INCOME SMOOTHING PRACTICES IN MALAYSIAN ISLAMIC BANKS: ROBUST STATISTICAL ANALYSIS
}

\author{
Noor Fadhzana Mohd Noor ${ }^{1 *}$ and Juliza Mohamed ${ }^{2}$ \\ ${ }^{I}$ Faculty of Education and Social Sciences, Universiti Selangor (UNISEL), \\ Bestari Jaya Campus, Jalan Timur Tambahan, 45600 Bestari Jaya, \\ Selangor, Malaysia \\ ${ }^{2}$ Faculty of Business and Accountancy, Universiti Selangor, Shah Alam Campus, \\ Jalan Zirkon A7/A Seksyen 7, 40000 Shah Alam, Selangor, Malaysia \\ *Corresponding author: fadhzana@unisel.edu.my
}

Published online: 20 March 2019

To cite this article: Noor, F.M.N. and Mohamed, J. (2019). Profit equalisation reserve and income smoothing practices in Malaysian Islamic banks: Robust statistical analysis. Asian Academy of Management Journal, 24(Supp.1), 79-92. https://doi.org/10.21315/ aamj2019.24.s1.6

To link to this article: https://doi.org/10.21315/aamj2019.24.s1.6

\begin{abstract}
The objective of this study is to ascertain the use of profit equalisation reserve (PER) to mitigate displaced commercial risk (DCR). This study proposes that the use of PER will be linked to smoothing practices, i.e., the earnings management (EM), capital management (CM), profit distribution management (PDM), and investment structures (IS). Using Pool and Panel OLS models, the results show that there are significant relationships between PER and CM, PDM, and long-term investment structure (LTIS). Thus, the results suggest the use of PER by banks with bigger capital to cushion for future DCR, to smooth profit pay-outs as well as its use to manage the possible DCR in LTIS. The results of this study however have failed to reject PER's use in EM by the banks.
\end{abstract}

Keywords: profit equalisation reserve, earnings management, capital management, profit distribution management, Islamic banks

(C) Asian Academy of Management and Penerbit Universiti Sains Malaysia, 2019. This work is licensed under the terms of the Creative Commons Attribution (CC BY) (http://creativecommons. org/licenses/by/4.0/). 


\section{INTRODUCTION}

The salient feature of Islamic banks is the shariah principles they adhere to. According to the shariah principles, Islamic banks cannot rely on fixed rate of income, which is normally generated through interest (riba). Hence, investmentbased products that are based on mudharabah (partnership) have been the alternative products for them (Siddiqui, 2008). Because of the products, Islamic banks are exposed to unique risks such as rate of return risk (RORR) as well as the displaced commercial risk (DCR) (Archer, Abdel Karim, \& Sundararajan, 2010; Toumi, Viviani, \& Belkacem, 2010). To overcome DCR, some of the Islamic banks rely on profit equalisation reserve (PER). This reserve is a risk mitigation tool to reduce the effect of DCR in Islamic banks (IFSB, 2005; Sundararajan, 2005, 2008; Taktak, 2011; Muhannad \& Ramadan, 2012). In the Malaysian context, a specific guideline on PER has been issued by Bank Negara Malaysia (BNM) in 2012. Nonetheless, the function of the reserve and the guidelines have been minimised through the implementation of Islamic Financial Services Act (IFSA) in 2013 as the effect of downsizing of mudharabah products (Islamicbankers, 2015). Although the function of the reserve is reducing, the insights of the reserve has not been adequately addressed in the past. Therefore, the findings of this study are confined to academic purposes only.

\section{LITERATURE REVIEW}

\section{Profit Equalisation Reserve (PER)}

PER is defined as a reserve comprised of amounts appropriated out of the gross income from the mudharabah (investment fund) to be available for smoothing returns to be paid to the investment account holders (IAHs) and the banks' shareholders (IFSB, 2010). Thus, PER consists of a profit sharing investment account (PSIA) portion and a shareholder's portion (IFSB, 2010). In practice, PER is appropriated from investment profits (derived income) before it is attributed to the shareholders and IAHs. This appropriation is made after deduction on allowance on impairment of financing and advances or loan loss provision (LLP) and loan loss investment (LLI) (Ramli, Shahimi, \& Ismail, 2012). Theoretically, PER collectively belonged to the IAHs and the banks' shareholders. Thus, the amounts appropriated to the PER reduce the profits available for distribution to both banks' shareholders and IAHs. The amounts appropriated to the PER allows the Islamic banks to considerably reduce their exposure to DCR and related problems of asset-liability management. Even though the function of PER is to enhance the profit pay-out to IAHs when the Islamic banks are exposed to the DCR, it is also 
the case that the PER can be used for smoothing or enhancing dividend pay-outs to shareholders if so desired by the management. It this way, there is a moral hazard due to asymmetric information. This is the case when it is apparent that the banks' shareholders may benefit from the PER, but it is less clear that IAHs do so.

\section{PER and the Smoothing Practices}

Several empirical studies have been conducted to analyse the practice of PER. One has been conducted to examine the provisioning behaviour of PER. It focused on the underlying determinants of PER in Malaysian Islamic banks (Ismail \& Shahimi, 2006). This study found that the banking regulators in Malaysia view PER as a reserve that is built up in good times to cater the need during bad times. Thus, the actual estimates of PER are determined by each bank's management. Taktak (2011) who studied the nature of smoothing returns has found that most Islamic banks, particularly in Bahrain, relied on natural smoothing, or smoothing based on Islamic accounting standard compared to intentional smoothing or smoothing based on discretionary power. Sundararajan (2005) who studied the risks of Islamic banks also slightly examined the provisioning of PER by 14 Islamic banks in eight countries. He found that only $30 \%$ of them disclosed the information on PER. Another related study would be Taktak, Zouari, and Boudriga (2010) who studied the use of loan loss provision (LLP) and found insignificant relationship between the LLP and the smoothing practices. Rather, they suggested that the banks may have relied on PER and investment risk reserve (IRR).

The past literature also explored the practices of earnings management (EM) and capital management (CM) by Islamic banks. In investigating EM and CM, the literature employed discretionary reserve, i.e., LLP as the independent variable, both in global and Malaysian contexts (Ahmed, Takeda, \& Thomas, 1999; Beidleman, 1973; Eckel, 1981; Farook, Hassan, \& Clinch, 2014; Ismail, Shaharudin, \& Samudhram, 2005; Misman \& Ahmad, 2011; Taktak et al., 2010). In the study of EM and CM, the researchers have landed on multiple findings. In Ramli et al. (2012) and Hamdi and Mohamed Zarai (2013), the relationships between PER and EM and CM were studied. The former study was conducted to explore EM and CM through PER. The study found that Tier 1 capital is a significant determinant of PER, where a significant negative relationship was reported. It was also found that total earnings before taxes and zakat (alms) was not significantly related to PER. The inclusion of PER in profit distribution management (PDM) was contributed by several researchers like Farook et al. $(2014,2012)$ and Hamdi and Mohamed Zarai (2013). PDM refers to the act of banks to manage the actual derived profit when distributing to customers. This is inherent in Islamic banks since they have "implicit flexibility to manage their depositor profit distributions 
ex post as a result of being able to vary the management fee attributable to the shareholders" (Farook et al., 2012, p. 333). Thus, the inclusion of PER in Islamic banks' PDM is plausible. In the former study, it was evident that when Islamic banks maintain a discretionary reserve, i.e., PER, they tend to manage their profit towards the interest rates and away from the fundamental profit. This means that PER is a determinant to PDM. This study used data of Islamic banks from 1993 to 2005 (Farook et al., 2012). PDM in Islamic banks was also exhibited in the latter study (Hamdi \& Mohamed Zarai, 2013).

In practice, the use of PER amount is variant due to the investment structures (IS) the banks have. IS of Islamic banks are of important aspect to PER because the investment with longer maturity exposed the Islamic banks to higher DCR. Although this aspect has not been investigated, it is an important insight of the use of PER in the smoothing practices.

\section{Displaced Commercial Risk (DCR)}

On the other hand, DCR is a specific risk that arises from the assets managed on behalf of the IAHs (BNM, 2011; IFSB, 2010). This risk emerges when the returns of the investment accounts (IA) is lower than those offered by the conventional banks. In the long run, DCR is sophisticating the position of the Islamic banks to cope with the competition it has in a dual banking system. This scenario is also the impact of reliance on conventional benchmarking (Archer et al., 2010; Toumi et al., 2010). For instance, when the volatility of interest rates in deposit accounts in high, the exposure of DCR on the Islamic banks become higher as well (Hutapea \& Kasri, 2010). As such, the Islamic banks need to increase their deposit rate or to decrease their financing rate or operate at a lower margin. At the same time, studies on DCR, or particularly RORR, are still lacking in the literature (Zainol \& Kassim, 2012).

\section{METHODOLOGY}

To employ the appropriation of PER, a few measures were taken. In Ramli et al. (2012), it was found that PER is a reserve built from the returns derived from both depositors and shareholders' funds. With deduction of certain allowances, the amount of PER can be deduced. Although it may be the case during the period the study was conducted, this current study found it to be inadequate. Thus, PER was taken directly from the Islamic banks' financial reports and the missing value of PER was replaced with average value from three years of data of that particular bank. 
To ascertain that PER's use in smoothing practices, this study employed several approaches. The first approach was by ascertaining the relationship between PER and EM. This was done by investigating the relationship between PER and earnings of the banks. EM as variable was calculated by earnings before deduction of zakat and taxation of bank $i$ at year $t$ normalised by total asset. Secondly was the relationship between PER and CM. CM was measured by Tier I capital divided by bank $i$ at year $t$ normalised by total asset. This study anticipated a significant relationship between PER and both EM and CM. Significant negative relationship between PER and EM suggests that whenever a bank's earnings drop (due to the impact of among others, DCR) then PER would be smaller for that particular year to smooth the total earnings of the banks. In contrast, positive relationship of PER and CM was anticipated since the banks with smaller capital are more likely to reduce PER to increase its capital adequacy ratio (CAR). Simultaneously, banks with bigger capital would tend to build up their PER to cushion for future DCR. Earnings before tax and zakat (EM) has been used by several studies (Ahmed et al., 1999; Farook et al., 2014; Misman \& Ahmad, 2011; Ramli et al., 2012; Taktak et al., 2010) to imply EM and the primary capital or Tier I was used for $\mathrm{CM}$.

The third approach was PDM. This approach was analysed using several variables, namely smoother (SM) (Hamdi \& Mohamed Zarai, 2013; Eckel, 1981), asset spread (AS) (Farook et al., 2012), and derived income spread (DIS). SM uses dummy variables to differentiate banks that are profit pay-out smoother and profit pay-out non-smoother. This variable was measured by the coefficient of variation of profit pay-out changes over the coefficient of variation of net income changes. A ratio smaller than 1 indicates a lower variability in profit pay-out compared to the net income variability, thus suggesting the bank as profit pay-out smoother and ratio equals or bigger than 1 suggests the bank as profit pay-out non-smoother (Hamdi \& Mohamed Zarai, 2013). For the SM, dummy variables were utilised. In this regard, 1 equals to smoother and 0 equals to non-smoother. Thus, PER was expected to be negatively linked to the SM as it may explain the use of PER in profit pay-out smoothing. The negative relationship implicitly explains the impact of DCR on Islamic banks. Another variable was the AS. AS is the absolute spread between the return on asset (ROA) (after excluding profits attributed to depositors) and the return on investment account holder (ROIAH). This is considered the closest indicator of the spread between total asset return on bank's asset and return paid to the depositors (Hamdi \& Mohamed Zarai, 2013). To construe the assumption that Islamic banks are exposed to DCR thus causing the use of PER, the AS was expected to be bigger. The bigger value of the AS suggests that the Islamic banks have turned away from the fundamental profit or smooth the profit pay-outs. This spread was anticipated to be positively 
related to PER. A common limitation of this variable is the effect of aggregation of the depositors' profit rates and there is no viable method by which the exact depositor rates of profit can be determined for each type of investment account (Farook et al., 2012, 2014). In addition, the relationship between PER and the DIS, i.e., the spread between realised profit and attributable profit or profit payout to depositors and banks was also anticipated. This spread was calculated through the spread between the realised profit from depositors and derived profit from shareholders and the spread between profit paid to the depositors and profit allocated back to the bank. When the DIS is in a positive value, it shows that the bank did not smooth the income and vice versa. The relationship between PER and DIS should be in significant negative value.

The fourth approach was the investment structures (IS). The IS comprised of two sets of variables. They are the short-term investment structure (STIS) and longterm investment structure (LTIS). The assumption is that the maturity or period of IS is important because DCR arises from the effect of RORR. For instance, Islamic banks may invest the IAH funds into long-maturity assets (LTIS) that produce lower RORR compared to the prevailing market expectations. Thus, any action by the Islamic banks to cope with the RORR as expected by the market is an exposure to DCR. The LTIS is the total long-term investments held by bank $i$ at year $t$ normalised by total asset. It consists of investments which maturity are for the period of $1-3$ years, $3-5$ years, and above 5 years. The STIS is the total shortterm investments held by bank $i$ at year $t$ normalised by total asset. It consists of investments which maturity are for the period of below six months and six months to one year.

Bank specifics comprised bank's size (SIZE), bank's ownership (OWN), and bank's experience (EXP) were taken as the control variables. The bank's size was proxied by logarithm of bank's total asset. This variable was used to control for the bank's capital (Berger \& Bouwman, 2013), hence, positive relationship was anticipated. Bank's ownership (OWN) was employed to control for earnings. In Abdul Rahman and Md Rejab (2015), bank's ownership was hypothesised to be linked to earnings because of the nature of foreign banks that usually hold bigger capital, better ability to diversify risk, and better expertise. Dummy variable to indicate ownership of bank, 1 equals to local ownership of bank and 0 equals to foreign ownership of the bank, were used in this study. Thus, negative relationship was expected between EM and OWN. Bank's experience (EXP) was used as a control variable for IS. Dummy variables were used, 1 equals to years of operation over 10 years and 0 equals to years of operation below 10 years. Banks operating the Islamic banking business for a shorter time was expected to be negatively related to IS since the banks may be risk averse and vice versa. Thus, positive 
and negative relationships can be observed between EXP and LTIS and STIS, respectively.

Thus, the hypotheses of this study can be summarised as below:

H1: There is a significant positive relationship between PER and EM.

H2: There is a significant positive relationship between PER and CM.

H3: There is a significant relationship between PER and PDM.

H4: There is a significant relationship between PER and IS.

\section{Sample Selection}

Data was collected from the annual reports of 16 Islamic banks in Malaysia, both local and foreign banks from the year 2008 to 2013. This is almost the subsequent years from Ramli et al. (2012), conducted from 2003 to 2010 on all Malaysian Islamic banks, comprising of 15 banks. The data used in this study was compiled from the banks' financial reports. Due to unavailability of data on PER, only 11 Islamic banks were maintained.

\section{Estimation Method}

Pool and Panel Ordinary Least Square (OLS) regressions were utilised to ascertain the relationship between PER and EM, CM, PDM, and IS. The estimation method is as follows:

$$
\begin{aligned}
\text { PER }= & \mathrm{f}(\mathrm{EM}, \mathrm{CM}, \mathrm{SM}, \mathrm{AS}, \mathrm{DIS}, \mathrm{LTIS}, \mathrm{STIS}, \mathrm{EXP}, \mathrm{SIZE}, \mathrm{OWN}) \\
\operatorname{rper}_{i t}= & \beta_{0}+\beta_{1} E M_{i t}+\beta_{2} r C M_{i t}+\beta_{3} S M+\beta_{4} A S_{i t}+\beta_{5} D I S_{i t}+\beta_{5} L T I S_{i t} \\
& +\beta_{7} \text { STICS }_{i t}+\beta_{8} E X P+\beta_{9} S I Z E_{i t}+\beta_{10} O W N+\varepsilon_{i t}
\end{aligned}
$$

\section{RESULTS}

\section{Descriptive Statistics}

Table 1 displays the descriptive statistics for all variables. The mean and standard deviation of PER is $0.19 \%$ and $0.32 \%$, respectively. The values are slightly different from Ramli et al. (2012) who found that the mean of PER was $-0.01 \%$ and the standard deviation was $0.28 \%$. It may be due to the different calculation or measurement used to produce the value of PER (appropriation of PER by the banks). The study calculated PER using a formula, i.e., total income minus the 
LLP and LLI. However, this current study extracted the exact amount of PER as reported in the financial reports (with addition of mean value of three years disclosed amount whenever the amount of PER is not available). The mean and standard deviation of total earning before taxation and zakat over total asset (EM) was $1.88 \%$ and $3.05 \%$, respectively. This is again different from the previous data (Ahmed et al., 1999; Ramli et al., 2012; Taktak et al., 2010) but consistent with Misman and Ahmad (2011). The difference may be justified by the different set of data in terms of period and bank since this research excluded five Islamic banks from the original data. The exclusion was because of the report of the stopping of PER policy as profit pay-out smoothing tool by the banks. In addition, several Islamic banks which reported loss within the period of study coincidently appear to be those which do not maintain PER. The mean and standard deviation of Tier 1 capital (CM) is consistent with the previous study data (Ramli et al., 2012) at $8 \%$ and $5 \%$ to the total asset, respectively. AS produces slightly different result as compared to that in Farook et al. (2012). This may be explained on the nature of the data whereby the study was conducted on Islamic banks from 17 countries and reported average AS for all Islamic banks in Malaysia. In this study, AS of individual bank were extracted. The mean and standard deviation for AS were $-3 \%$ and $2 \%$, respectively. The DIS variable reports the mean value of $3 \%$ and the standard deviation was $2 \%$. The LTIS and SRIS report value of mean of $3 \%$ and $77 \%$ over the total asset, respectively. While their standard deviations were $1 \%$ and $49 \%$, respectively. The difference between the two IS is huge since most Islamic banks rely on STIS to produce immediate profit. Bank's size or logarithm of total asset reports the mean of 24 and standard deviation 1.7. This is quite different with the previous data (Ramli et al., 2012) but consistent with the overall data where the range was 22 to 28 .

Table 1

Descriptive analysis of all variables

\begin{tabular}{lcllllll}
\hline Variable & Mean & Median & Std. dev & Min & Max & Skewness & Kurtosis \\
\hline PER & 0.1885 & 0.08914 & 0.3244 & 0 & 1.74393 & 3.151495 & 13.48098 \\
EM & 1.882281 & 1.305026 & 3.054739 & 0.078096 & 25.09644 & 6.790468 & 52.12414 \\
CM & 8.454835 & 7.38498 & 4.684285 & 0.984093 & 31.28213 & 2.322256 & 10.47511 \\
SM & 0.909091 & 1 & 0.289683 & 0 & 1 & -2.84605 & 9.1 \\
AS & -3.2303 & -3.15 & 2.121898 & -11.7 & 0.5 & -1.38403 & 6.828886 \\
DIS & 3.360697 & 3.897175 & 2.113805 & -1.31139 & 7.29678 & -0.60974 & 2.521903 \\
LTIS & 3.124504 & 1.70615 & 4.453121 & 0 & 23.60491 & 2.344241 & 9.15178 \\
STIS & 77.23097 & 49.7151 & 115.1786 & 5.87618 & 645.9069 & 3.811472 & 16.96362 \\
EXP & 0.545455 & 1 & 0.501745 & 0 & 1 & -0.18257 & 1.033333 \\
OWN & 0.636364 & 1 & 0.484732 & 0 & 1 & -0.56695 & 1.321429 \\
SIZE & 23.86058 & 23.46754 & 1.74543 & 21.80975 & 28.69681 & 1.593853 & 4.955568 \\
\hline
\end{tabular}




\section{Regression Analysis}

All tests were checked for significance collinearity by reviewing the variance inflation factor (VIF) for each variable. The correlation coefficients among the independent variables were low (less than 0.80) suggesting the absence of multicollinearity problems. For each test conducted, the VIF indicated a value below 4.0, again to strengthen the absence of multicollinearity. The control variables produced expected relationships. The SIZE variable was used to control for the bank's capital (Berger \& Bouwman, 2013) and it is in a positive relationship with CM as indicated in Table 2. Bank's ownership (OWN) was employed to control for EM. The correlation matrix yielded a negative relationship between OWN and EM.

Bank's experience (EXP) was used as a control variable for LTIS and STIS. Dummy variables were used, 1 equals to years of operation over 10 years and 0 equals to years of operation below 10 years. Banks that have been operating the Islamic banking business for shorter year were expected to be negatively related to STIS since the banks may be risk averse. Banks that have been operating Islamic banking less than 10 years are thus linked positively with the LTIS as indicated in Table 2 .

Table 2

Correlation matrix (all variables)

\begin{tabular}{lcccccccccc}
\hline & EM & CM & SM & AS & DIS & LTIS & STIS & EXP & OWN & SIZE \\
\hline EM & 1 & & & & & & & & & \\
CM & 0.0478 & 1 & & & & & & & & \\
SM & 0.0479 & 0.0993 & 1 & & & & & & & \\
AS & 0.3102 & 0.1708 & -0.0646 & 1 & & & & & & \\
DIS & 0.2605 & -0.0657 & -0.2764 & 0.2676 & 1 & & & & & \\
LTIS & 0.1894 & -0.1085 & -0.0572 & -0.0347 & 0.2398 & 1 & & & & \\
STIS & -0.034 & -0.0795 & 0.0673 & -0.0502 & 0.0627 & -0.0182 & 1 & & & \\
EXP & 0.1001 & 0.1836 & -0.2887 & 0.2744 & 0.0755 & -0.1135 & -0.0168 & 1 & & \\
OWN & -0.1451 & -0.2469 & -0.239 & -0.0303 & 0.4791 & 0.2889 & -0.0715 & 0.069 & 1 & \\
SIZE & -0.1181 & 0.317 & -0.0583 & 0.0744 & -0.2879 & -0.3538 & -0.1751 & 0.3616 & -0.0862 & 1 \\
\hline
\end{tabular}

This study employs Pool OLS and Panel OLS models. The purpose of the estimation was to ascertain the relationship between PER and EM, CM, PDM, and IS. This research extended the regression results to select the best model among OLS, fixed effect (FE), and random effect (RE). By conducting Breusch and Pagan Lagrangian multiplier test for random effects, the results produced prob $>$ chi $=0.000$, thus rejecting the null hypothesis of the homogeneity of data 
and Panel OLS was selected. Subsequently, FE and RE models were used. Based on the results of Hausman test (1978), it was reported that prob $>$ chi $=0.009$. Therefore, the null hypothesis cannot be rejected. The conclusion of this test was that the RE model was more appropriate. Pool OLS, FE, and RE models were employed on independent variables, not inclusive of dummy variables. This is due to the nature of both FE and RE that involve subtracted group means from the regressors and the mean values were only applicable to time varying regressors in the model. Therefore, all the dummy variables were excluded.

H1 predicts that there is a significant positive relationship between PER and EM. Based on the previous study by Ramli et al. (2012), PER was anticipated to be positively related to earnings indicating that the bank uses PER to smooth earnings. Whereas in this current research, PER was predicted to be positively related to EM to support the assumption that PER has been actively utilised by Islamic banks to mitigate DCR thus, evidencing positive relation between PER and earnings. In other words, when a bank is adversely affected by DCR, PER would be utilised effectively, therefore, whenever earnings decreases, PER will decrease as well. As the result, the profit pay-out can be smoothened to both depositor and the bank using PER. However, based on the regression result, PER was found to be negatively related to PER but the relationship was insignificant. Thus, the null hypothesis is rejected.

As predicted, there is a positive relationship between PER and CM. According to H2, there was a positive relationship between PER and Tier I capital since the bank with higher capital will tend to allocate bigger proportion of PER to cushion for future DCR. On the other hand, banks with smaller capital will reduce PER to increase their capital adequacy ratio. This result is supported by Ismail and Shahimi (2006) who found the positive relationship between PER and capital. However, the result contrasted with that of Ramli et al. (2012). It may be due to the different measures employed to calculate the PER as well as year and number of observations. Therefore, the null hypothesis is accepted, at $p$-value $=0.000$.

H3 relates PER to the PDM. In Hamdi and Mohamed Zarai (2013), the variation between profit pay-out changes over net income changes measure has been utilised. This study also employed the same variables, i.e., dummy variables (SM). The predicted sign was negative, where whenever the bank smoothens its income, it is likely to be negatively related to PER. Based on the regression result in the Pool OLS model, the relationship observed was negative but not significant. Thus, the null hypothesis is rejected. In Farook et al. (2012, 2014), three approaches were utilised to ascertain the relationship between existence of discretionary reserve, inclusive of PER and PDM, i.e., through asset spread, deposit spread, and equity 
spread. The additional AS and DIS were utilised in this study. This study assumes that whenever the bank is affected by DCR, the fundamental returns would be smoothed, and this would like to be related to PER. The predicted relationship was positive between PER and AS. When a bank has bigger spread (AS), this indicates smoothing of profit pay-out, likely due to DCR, then PER is expected to relate to it positively. In Farook et al. (2012), dummy variables were used to proxy PER, and other discretionary reserve. They found that there was a significant relation between PER and PDM, that showed the ability to manage profit distribution increased with the creation of dedicated discretionary reserve. Findings of this study found a positive relationship between AS and PER at slightly weak significant level, $p$-value $=0.066$.

H3 is also supported by another variable, the DIS. A significant negative relation between PER and DIS was expected. When the DIS is in positive value, it shows that the bank do not smooth the profit to the depositors and vice versa. This DIS is thus predicted to be in significant negative relationship with PER. Based on study by Sundararajan (2005), and in support of Farook et al. (2014), the DIS should be in negative value since the shareholders may enjoy bigger income due to higher risks they are facing. In contrast, this research found a positive mean value and negative relation between PER and the spread at $p$-value $=0.027$.

To strengthen the assumption that Islamic banks practice in PDM due to DCR, H4 was developed. To support H4, a significant positive relation between PER and LTIS was anticipated. The intuition is that if the bank is affected by DCR, a significant positive relationship between PER and the LTIS can be anticipated and simultaneously an inverse significant relationship with STIS can be expected. As reported in Table 3, there is a significant positive relation between PER and LTIS, at $p$-value $=0.000$. Unfortunately, the expected inverse relation did not occur between PER and STIS. Still, the null hypothesis is accepted.

Table 3

Regression analysis

\begin{tabular}{cccc}
\hline & Pool OLS & Fixed effect & Random effect \\
\hline \multirow{4}{*}{ EM } & PER & PER & PER \\
& -0.00274 & -0.00483 & -0.00414 \\
CM & $(-0.33)$ & $(-0.96)$ & $(-0.82)$ \\
& $0.0425^{* * *}$ & $0.0349^{* * *}$ & $0.0318^{* * *}$ \\
& $(8.07)$ & $(6.48)$ & $(6.88)$ \\
\hline & & & (continued on next page)
\end{tabular}


Table 3 (continued)

\begin{tabular}{lccc}
\hline & Pool OLS & Fixed effect & Random effect \\
\hline \multirow{2}{*}{ SM } & -0.0973 & & \\
& $(-1.15)$ & & \\
AS & 0.0105 & 0.0134 & 0.0113 \\
& $(0.90)$ & $(1.88)$ & $(1.59)$ \\
DIS & 0.00854 & $-0.0262^{*}$ & $-0.0253^{*}$ \\
& $(0.59)$ & $(-2.19)$ & $(-2.20)$ \\
LTIS & $0.0237^{* * *}$ & $0.0175^{* *}$ & $0.0166^{* * *}$ \\
& $(4.18)$ & $(3.49)$ & $(3.49)$ \\
STIS & -0.0000842 & -0.0000782 & -0.000116 \\
& $(-0.43)$ & $(-0.57)$ & $(-0.84)$ \\
EXP & $-0.296^{* * *}$ & & \\
& $(-5.73)$ & & \\
OWN & $0.134^{*}$ & & $(-1.71)$ \\
& $(2.23)$ & & 1.163 \\
SIZE & $-0.0571^{* * *}$ & -0.0138 & $(1.62)$ \\
& $(-3.58)$ & $(-0.36)$ & 66 \\
cons & $1.300^{* *}$ & 0.314 & \\
& $(3.23)$ & $(0.32)$ & \\
N & 66 & 66 & \\
\hline
\end{tabular}

\section{CONCLUSION}

This research is an attempt to understand the use of PER by Islamic banks and its determinants. By looking at four dimensions, i.e., EM, CM, PDM, and IS, using both Pool and Panel OLS estimations, it can be concluded that PER has been provisioned by Islamic banks as displaced commercial risk (DCR) mitigation tool. The most significant variables associated with PER are CM and LTIS.

\section{ACKNOWLEDGEMENTS}

Financial support is acknowledged from Ministry of Education (MoE) Malaysia under the Exploratory Research Grant Scheme (ERGS) (ERGS/1/2013/SS05/ UNISEL/03/01). We also acknowledge the support of our home institution, Universiti Selangor (UniSEL), and the Research and Development Unit, i.e., Business, Research Linkages and Consultancy (BRIC) particularly. 


\section{REFERENCES}

Abdul Rahman, N.A., \& Md Rejab, A.F. (2015). Ownership structure and bank performance. Journal of Economics, Business and Management, 5(3), 483-488. https://doi.org/10.7763/JOEBM.2015.V3.232

Ahmed, S.A., Takeda, C., \& Thomas, S. (1999). Bank loan loss provisions: A reexamination of capital management, earnings management and signaling effects. Journal of Accounting and Economics, 28(1), 1-25. https://doi.org/10.1016/S0165-4101(99) 00017-8

Archer, S., Abdel Karim, R.A., \& Sundararajan, V. (2010). Supervisory, regulatory and capital adequacy implications of profit sharing investment accounts in Islamic Finance. Journal of Islamic Accounting and Business Research, 1(1), 10-31. https://doi.org/10.1108/17590811011033389

Beidleman, C.R. (1973). Income smoothing: The role of management. Accounting Review, 48(4), 653-667.

Berger, A.N., \& Bouwman, C.H.S. (2013). How does capital affect bank performance during financial crises? Journal of Financial Economics, 109, 146-176. https://doi.org/10.1016/j.jfineco.2013.02.008

BNM (Bank Negara Malaysia). (2011). Framework of the rate of return. Retrieved 11 June 2018 from http://iimm.bnm.gov.my

BNM (Bank Negara Malaysia). (2012). Guidelines on profit equalization reserve (PER). (BNM/RH/GL 008-012). Retrieved 11 June 2018 from http://www.bnm.gov.my/ guidelines

Eckel, N. (1981). The income smoothing hypothesis revisited. Abacus, 1(17), 28-40. https://doi.org/10.1111/j.1467-6281.1981.tb00099.x

Farook, S., Hassan, M.K., \& Clinch, G. (2012). Profit distribution management by Islamic banks: An empirical investigation. The Quarterly Reviews of Economics and Finance, 52(3), 333-347. https://doi.org/10.1016/j.qref.2012.04.007

Farook, S., Hassan, M.K., \& Clinch, G. (2014). Islamic bank incentives and discretionary loan loss provision. Pacific Basin Finance Journal, 28, 152-174. https://doi. org/10.1016/j.pacfin.2013.12.006

Hamdi, F., \& Mohamed Zarai, M.A. (2013). Perspectives of earnings management in Islamic banking institutions. International Journal of Management and Business Invention, 2(9), 26-38.

Hutapea, E.G., \& Kasri R.A. (2010). Bank margin determination: A comparison between Islamic banks and conventional banks in Indonesia. International Journal of Islamic and Middle Eastern Finance and Management, 3(1), 65-82. https://doi. org $/ 10.1108 / 17538391011033870$

IFSB (Islamic Financial Services Board). (2005). Revised capital adequacy standard for institutions offering only Islamic financial services [Excluding Islamic insurance (Takaful) institutions and Islamic collective investment schemes]. Retrieved 13 June 2018 from https://www.ifsb.org/standard/2014-01-28_eng_IFSB15\%20 Revised\%20Capital\% 20Adequacy_(Jan\%202014).pdf 
IFSB (Islamic Financial Services Board). (2010). Guidance note on the practice of smoothing the profits payout to investment account holders. Retrieved 13 June 2018 from https://www.ifsb.org/standard/eng_GN-3_Guidance_Note_on_the Practice_of_Smoothing.pdf

Islamicbankers. (2015). The mudharabah, the deposits and the investment accounts. Retrieved 20 May 2018 from https://islamicbankers.me/2015/01/02/investmentaccounts

Ismail, A.G., Shaharudin, R.S., \& Samudhram, A.R. (2005). Do Malaysian banks manage earnings through loan loss provisions? Journal of Financial Reporting and Accounting, 3(1), 41-47. https://doi.org/10.1108/19852510580000336

Ismail, A.G., \& Shahimi, S. (2006). An empirical analysis of profit equalization reserve decisions. Retrieved 27 November 2015 from http://pkukmweb.ukm.my/ ekonis

Misman, F.N., \& Ahmad, W. (2011). Loan loss provisions: Evidence from Malaysian Islamic and conventional banks. International Review of Business Research Papers, 7(4), 94-103.

Muhannad, A.A., \& Ramadan, A.H. (2012). A critique on accounting of the mudarabah contract. Journal of Islamic Accounting and Business Research, 1(3), 7-19.

Ramli, R., Shahimi, S., \& Ismail, A.G. (2012). Do Malaysian Islamic banks manage earnings through profit equalisation reserve? Capital Markets Review, 20, 1-20.

Siddiqui, A.(2008). Financial contracts, risk and performance ofIslamic banking. Managerial Finance, 10(34), 680-694. https://doi.org/10.1108/03074350810891001

Sundararajan, V. (2005). Risk measurement and disclosure in Islamic finance and the implications of profit sharing investment accounts. In Proceedings of the Sixth International Conference on Islamic Economics, Banking and Finance, Jakarta, Indonesia, 21-24 November 2005. Jeddah: Islamic Development Bank and Islamic Research and Training Institute (IRTI).

Sundararajan, V. (2008). Issues in managing profit equalization reserves and investment risk reserves in Islamic banks. Journal of Islamic Economics, Banking and Finance, 1(4), 1-12.

Taktak, N.B. (2011). The nature of smoothing returns practices: The case of Islamic banks. Journal of Islamic Accounting and Business Research, 2(2), 142-152. https://doi.org/10.1108/17590811111170548

Taktak, N.B., Zouari, S.B.S., \& Boudriga, A.K. (2010). Do Islamic banks use loan loss provision to smooth their results? Journal of Islamic Accounting and Business Research, 1(2), 114-127. https://doi.org/10.1108/17590811011086714

Toumi, K., Viviani, J.L., \& Belkacem, L. (2010). Islamic banks' exposure to displaced commercial risk: Identification and measure. Retrieved 22 February 2019 from https://www.scribd.com/document/218778995/Islamic-Banks-Exposure-toDisplaced-Commercial-Risk-Identification-and-Measurement

Zainol, Z., \& Kassim, S. (2012). A critical review of the literature on return of rate risk in Islamic banks. Journal of Islamic Accounting and Business Research, 2(3), 121-137. https://doi.org/10.1108/17590811211265948 